\title{
Thermo-physical Properties Measurements of an Insulating Material Extracted from Different Date Palm Trees
}

\author{
${\text { Rachida Oaddi }{ }^{*} \text {, Rachid Tiskatine }}^{2}$, Mohamed Boulaid ${ }^{1}$, Lahcen Bammou $^{2}$, Ahmed Aharoune $^{2}$, Ahmed Ihlal $^{1}$ \\ ${ }^{1}$ Laboratory of Materials and Renewable Energies, Department of Physics, Faculty of Sciences, Ibn Zohr University, 80000 \\ Agadir, Morocco \\ ${ }^{2}$ Laboratory of Thermodynamics and Energetic, Department of Physics, Faculty of Science, Ibn Zohr University, 80000 \\ Agadir, Morocco
}

Corresponding Author Email: rachidaoaddi@gmail.com

https://doi.org/10.18280/i2m.180308

Received: 6 March 2019

Accepted: 17 May 2019

\section{Keywords:}

thermal insulation, thermo-physical properties, Transient Plane Source method, porous material, fiber orientation, waste materials

\begin{abstract}
During the last few decades, natural materials appear as a viable solution to current environmental problems and have been of interest to industry and researchers. The aim of this paper is to analyze the thermo-physical properties of a natural material extracted from three varieties of local date palm waste, called petiole, namely Boufeggous, Hafsa and Sair from Tinghir oasis, southern Morocco. A Transient Plane Source (TPS) method was used to measure the thermal conductivity and diffusivity of the proposed materials at different temperatures $\left(40{ }^{\circ} \mathrm{C}, 60^{\circ} \mathrm{C}, 80^{\circ} \mathrm{C}, 100{ }^{\circ} \mathrm{C}\right.$, and $\left.120^{\circ} \mathrm{C}\right)$. The thermo-physical properties, according to the orientation of the fibers at ambient temperature and atmospheric pressure, have been also conducted and analyzed. Furthermore, a scanning microscopy (SEM) analysis of the samples was conducted to characterize the palm microstructure. The results reveal low values of thermal conductivity which were about $0.070 \mathrm{~W} / \mathrm{m} . \mathrm{K}$. The microstructure analysis indicate that the proposed material is a highly porous and satisfies the thermal requirements of an insulating material. It worth to mention that this material will be used as insulation for a solar box cooker to reduce heat losses and enhance its performance.
\end{abstract}

\section{INTRODUCTION}

Materials obtained from natural sources processed with high-energy consumption such as glass or rock wools or from petrochemicals (mainly polystyrene) are commonly used as thermal insulating materials. Although, these materials have good physical properties, they are very expensive to acquire and highly polluting due to their $\mathrm{CO}_{2}$ manufacturing and their disposal environmental issues. The development of natural thermal insulating materials is rising sharply because of the increasing need to conserve the environment. Moreover, all researchers who have worked in the field of unconventional materials and their composites have agreed that these kinds of materials can offer environmental advantages such as lower pollutant and greenhouse gas emission. Furthermore, these natural materials are low cost with low density $[1,2]$.

Around the world, there are approximately 105 million palm trees covering an area of 800000 ha. Date palm plantations are distributed throughout the Middle East, North Africa, South Sahel, East and South Africa, the Southwestern United States of America and even in Southern Europe [3]. Furthermore, Morocco ranks the 6th in terms of area of palm trees and 11th in terms of production of dates [4]. Currently, the number of date palms in Morocco reaches 4.5 million, with more than $90 \%$ exists in the southern regions [5]. A main division of date palm parts is made as follows: the trunk, leaves, date fruits, petiole, mesh and cluster (Figure 1). Some of these parts are used to isolate land acres and protect them against sand encroachment and desertification as shown in Figure 2 .
A mature palm tree has approximately 30-140 leaves with spines and fibers on the petiole and forms an average of 1215 new leaves each year [6]. After the annual date fruit harvesting, the palms are cut and consequently a large quantities of date palm wastes accumulate every year. This renewable resource should find rational ways of recycling in order to protect the environment and to achieve economical benefits.

Recently, more and more researchers have become interested in date palm waste as natural fiber source with good thermal and mechanical properties and giving the opportunity to the development of new efficient materials already considered waste or used in low value products.

Tiskatine et al. [7] presented an experimental study on the thermal performance of new low cost composites based on natural materials for use in building construction in order to enhance the thermal comfort in buildings. The materials used in this study are widely available in the region of Souss Massa such as: sand, red clay, date palm waste, sawdust, straw and argan shell.

Ali et al. [8] experimentally investigated the possibility of using the date palm trees surface fiber (DPSF) as a new insulation material in building. Cornstarch is used as a resin to bind the fibers. Original insulating materials using palm tree and seaweed fibers in a cement matrix were studied by Boulaoued et al. [9]. Asdrubali et al. [10] report a state of art of innovative thermal and acoustical insulating materials realized using natural or recycled materials.

Benmansour et al. [11] proposed a new material composed of natural cement, sand and date palm fiber. The results 
reveal that the incorporation of date palm fibers reduces the thermal conductivity and the compressive strength of the composite. They concluded that using a suitable date palm fiber percentage in the mortar allows obtaining a composite with good thermal and mechanical properties which can be used to enhance the thermal insulation of building. Chikhi, et al. $[12,13]$ did an experimental study about gypsum based material containing date palm fiber. The thermo-physical behavior investigation shows that the increasing of fibers concentration in gypsum matrix decreases the thermal conductivity and the composites density.

The present work investigates the thermal properties of date palm waste, including petiole, in order to use it as an insulating material for a solar box cooker. The remainder of this paper is organized as follows: Section 2 presents a detailed description of the experimental setup and sample preparation, Section 3 discusses the finding results. Finally, Section 4 summarizes the paper and highlights some important recommendations for future related researches.

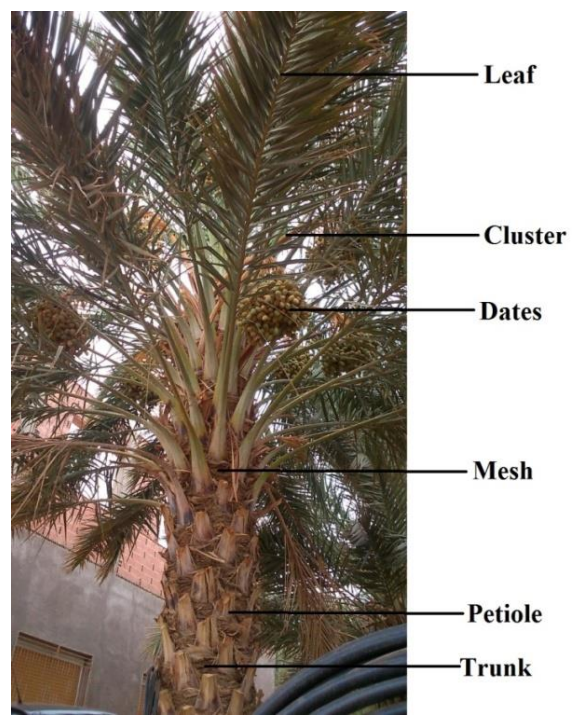

Figure 1. Different parts of a date palm tree

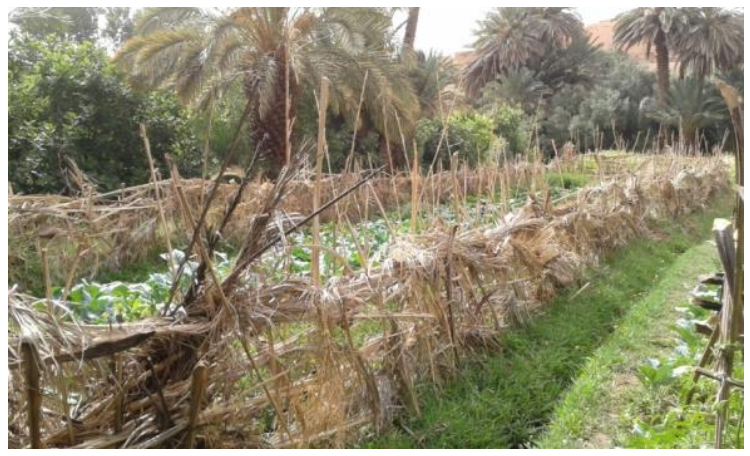

Figure 2. The use of some parts of the date palm tree to protect the plants

\section{EXPEREMENTAL SETUP}

\subsection{Raw materials and samples overview}

The natural materials used in this research are from three varieties of local date palm wood called petiole, namely hafsa, Boufeggous and Sair (local names), from Tinghir oasis, southern Morocco. Figure 3 shows a sample cut out from the petiole part.
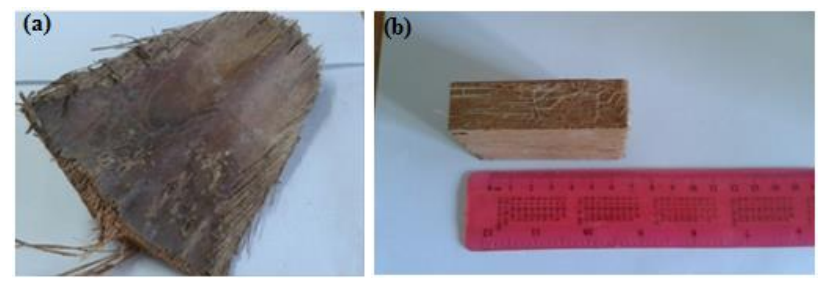

Figure 3. (a): Sample cut out from the petiole and (b):

Square plate shape to be used for inner insulating and for thermal characterization

\subsection{Characterization}

In order to evaluate the performances of date palm waste, we determined the thermo-physical and morphological properties of the samples. These parameters are important to characterize materials for thermal insulation.

Due to the anisotropic nature of the samples, the thermal measurements were conducted according to the orientation of fibers (longitudinal and transversal configuration).
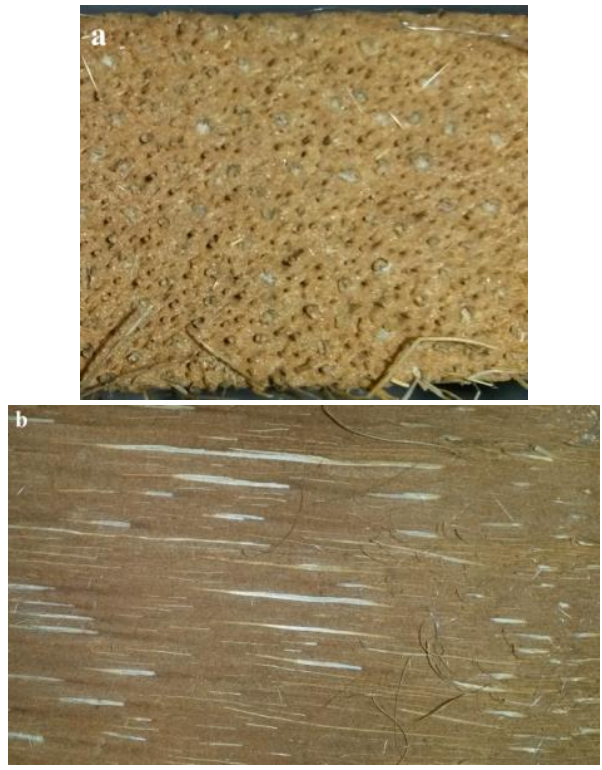

Figure 4. Petiole sample in (a) longitudinal direction of fibers and (b) transversal direction of fibers

\subsubsection{Thermal conductivity}

The main key property of a thermal insulation material is the thermal conductivity which is a property of a material to conduct heat, and where the normal goal is to achieve as low thermal conductivity as possible [14]. Low thermal conductivity values are required in order to minimize heat losses.

Thermal conductivity (k), defines the steady state heat flow passing through a unit area of a homogenous material, 1 $\mathrm{m}$ thick, inducted by a 1 Kelvin difference of temperature on its faces. It can be derived using the Fourier's law for heat conduction $[10,15]$.

$$
\begin{gathered}
\mathrm{Q}=-\mathrm{k} \delta \mathrm{T} / \delta \mathrm{xdAdt} \\
\mathrm{q}=-\mathrm{k} \nabla \mathrm{T}
\end{gathered}
$$


where, $\mathrm{Q}$ is the heat flux, $\delta \mathrm{T} / \delta \mathrm{x}$ the temperature gradient across a material layer, $A$ the surface area, $t$ the time and $k$ the thermal conductivity (W/m.K). Although materials with a thermal conductivity below $0.10 \mathrm{~W} / \mathrm{m} . \mathrm{K}$ are generally named as thermal insulating materials. However, this physical quantity remains one of the most difficult to measure, with many factors capable of influencing the thermal conductivity of this insulation material, including temperature, density, porosity, moisture and fiber direction [16]. Eq. 2 represents the three-dimensional form of Fourier's law. This equation describes the molecular transport of heat in isotropic media.

However, there are some solids, such as single non cubic crystals, fibrous materials and laminates that are anisotropic. For such substances we have to replace Eq. (2) by:

$$
\mathrm{q}=-\kappa \nabla \mathrm{T}
$$

\subsubsection{Thermal diffusivity}

Thermal diffusivity is a thermophysical parameter that plays a vital role in heat transfer in materials. It characterizes the ability of the material to transmit heat more or less rapidly. This quantity can be related to the thermal conductivity and the volume heat capacity by the relation:

$$
\mathrm{a}=\mathrm{k} / \rho \mathrm{c}
$$

\subsubsection{Measurement device}

The thermal conductivity (W/m.K) and diffusivity $\left(\mathrm{m}^{2} / \mathrm{s}\right)$ of date palm samples at different temperatures were measured using a thermal constants analyzer TPS 1500. The Transient Plane Source (TPS) technique is a nondestructive test method highly appreciated for its ability to simultaneously and quickly determine the properties cited above from a single measurement, with minimum sample preparation. The accuracy and the reproducibility are respectively better than $5 \%$ and better than $1 \%$. The results are displayed directly on the device screen. This method has been developed by Gustaffson [17] and it is based on using a two-sided Hot disk sensor made of nickel and kapton which was sandwiched in between of two identical pieces of sample being tested as in Figure 6.

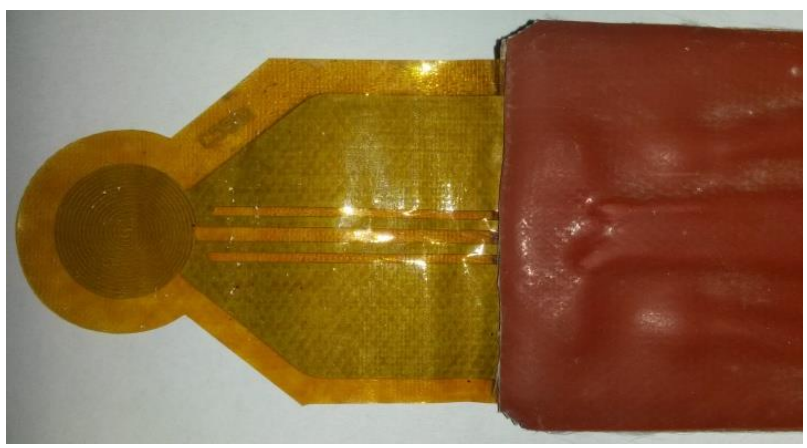

Figure 5. Picture of a TPS sensor

An electrical current pulse sufficient to increase the sensor temperature, and the temperature of the sample to rise (usually $2-5{ }^{\circ} \mathrm{C}$ ). From measurements of the change in sensor resistance during a constant power input a temperature difference can be measured between the actual sensor temperature and what the sensor temperature would be if there was no dissipation to the surrounding sample. In this capacity, the sensor acts as both the heat source and a dynamic temperature sensor. Importantly, the time duration of the electrical pulse must be sufficiently short that temperature gradients do not reach the sample boundaries during the time period of the test so that the material behaves like a semi infinite medium. An experimental oven type Binder connected with the TPS device was used to control and maintain the sample temperature at required temperature while its thermal conductivity was recorded. A part from the room temperature, the thermal conductivity was measured at elevated temperatures of $40{ }^{\circ} \mathrm{C}, 60{ }^{\circ} \mathrm{C}, 80{ }^{\circ} \mathrm{C}, 100{ }^{\circ} \mathrm{C}$ and $120{ }^{\circ} \mathrm{C}$, this covers the practical range of use in hot conditions.

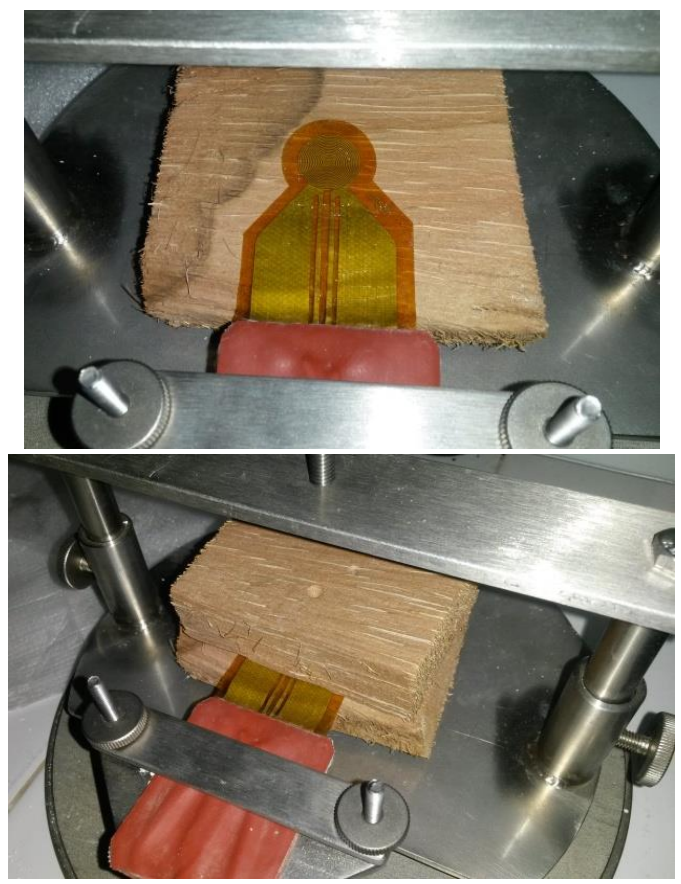

Figure 6. TPS sensor sandwiched between two samples for thermal tests measurements

\subsection{Microstructure analysis}

A scanning electron microscope (SEM) TESCAN VEGA3 LM is used to observe the surface morphology of the samples.

\subsection{Porosity measurement}

Wood is a porous material and porosity has its effect via air and/or water present in the voids and the distribution of these voids within the medium [18]. The volume fraction of porosity $(\emptyset)$ can be defined as the fraction of void space $\left(V_{p}\right)$ relative to the apparent total bulk volume $\left(V_{b}\right)$ of the sample.The mean porosity $(\varnothing)$ of thesamples was calculated by the following equation:

$$
\emptyset=\mathrm{V}_{\mathrm{p}} / \mathrm{V}_{\mathrm{b}}
$$

The materials used are cut into a cube to facilitate volume measurement. The samples were first dried in the oven at $90^{\circ} \mathrm{C}$ until their mass become constant. The mass was accepted to become constant when the change of mass between three consecutive weighing become less than $0.1 \%$ of the total mass, according to BS EN ISO 12571 [19]. When the samples have attained a constant mass, generally after around 8 hours, the materials were removed from the oven 
and placed in a glass full of water.

\section{RESULTS AND DISCUSSION}

Table 1 compares the thermal conductivity of studied samples and other common thermal insulation materials. It can be seen that, the thermal conductivity value of Hafsa petiole in transversal direction of fibers (PTH) is in the same range as those of hemp fibers, straw bale and coconut fiber [24-26]. The thermal conductivity values of Hafsa petiole in longitudinal direction of fibers (PLH), Boufeggous (PTB) and Sair (PTS) petioles in transversal direction of fibers are slightly higher than those of the materials cited above and is about two times lower than those of solid pine wood and corn cob [20, 22, 23].

Table 1. Thermal conductivity of studied samples and other natural materials

\begin{tabular}{|c|c|c|c|}
\hline Sample & $\begin{array}{l}\text { Density } \\
\mathrm{kg} / \mathrm{m}^{3}\end{array}$ & $\begin{array}{c}\text { Thermal } \\
\text { conductivity } \\
(\mathrm{W} / \mathrm{m} . \mathrm{K})\end{array}$ & Reference \\
\hline PLH & - & $0.0736 \pm 0.001$ & $\begin{array}{l}\text { Present } \\
\text { study }\end{array}$ \\
\hline PTH & - & $0.0670 \pm 0.001$ & $\begin{array}{l}\text { Present } \\
\text { study }\end{array}$ \\
\hline РTB & - & $0.0893 \pm 0.001$ & $\begin{array}{l}\text { Present } \\
\text { study }\end{array}$ \\
\hline PTS & - & $0.07642 \pm 0.001$ & $\begin{array}{l}\text { Present } \\
\text { study }\end{array}$ \\
\hline $\begin{array}{l}\text { Wood (pine, } \\
\text { Lauan) }\end{array}$ & $\begin{array}{c}450- \\
630\end{array}$ & 0.151 & [20] \\
\hline Hemp fibers & - & 0.0620 & {$[21]$} \\
\hline Corn cob & $\begin{array}{l}171- \\
334\end{array}$ & 0.101 & {$[22,23]$} \\
\hline Straw bale & $50-150$ & $0.038-0.067$ & {$[24,25]$} \\
\hline Coconut fiber & - & $0.046-0.068$ & [26] \\
\hline
\end{tabular}

\subsection{The influence of anisotropy on thermal conduction}

Petiole is an anisotropic material; consequently the thermal conductivity is different if heat is transferred perpendicularly or parallel with the fiber axis. The values of the thermal conductivity according to the orientation of fibers are also presented in Table 1 (PTH and PLH). The conductivity is slightly higher longitudinally than it is in a transverse direction, and these results are aligned with the scientific literature [9]. Since natural fibers consist of crystalline cellulose lattice that are radially arranged around its axis, they are highly anisotropic, which gives less thermal resistance along the axis compared to across the axis [10], [27]. Heat transfer is faster along the grain then across it.

\subsection{The influence of temperature on thermal properties}

The thermal conductivity (k) and thermal diffusivity (a) values, in the transversal direction, of the studied samples at $25^{\circ} \mathrm{C}, 40{ }^{\circ} \mathrm{C}, 60{ }^{\circ} \mathrm{C}, 80{ }^{\circ} \mathrm{C}, 100{ }^{\circ} \mathrm{C}$ and $120^{\circ} \mathrm{C}$ with the TPS method are plotted in figures 7 and 8 respectively. $\mathrm{k}$ and a are non linear function of temperature for each sample. With rising temperature, thermal conductivity reaches its maximum at $60{ }^{\circ} \mathrm{C}$, after that it reduces slightly with increasing in temperature until it reaches a certain point near to the initial value at room temperature. Thermal insulation materials, like other natural or man-made materials, exhibit temperature dependence of their properties that vary with the nature of the material and the temperature range.

As the temperature rises, the insulating medium (the air or gas within the voids) becomes more excited and its heat conduction gets boosted, and the radiation effect of the pore wall is strengthened [28]. Thermal conductivity as a function of temperature is an empirical relationship based purely on experimental data [29]. However, the thermal conductivities of most pure metals decrease with increasing temperature, whereas the conductivities of nonmetals increase; alloys show intermediate behavior [30].

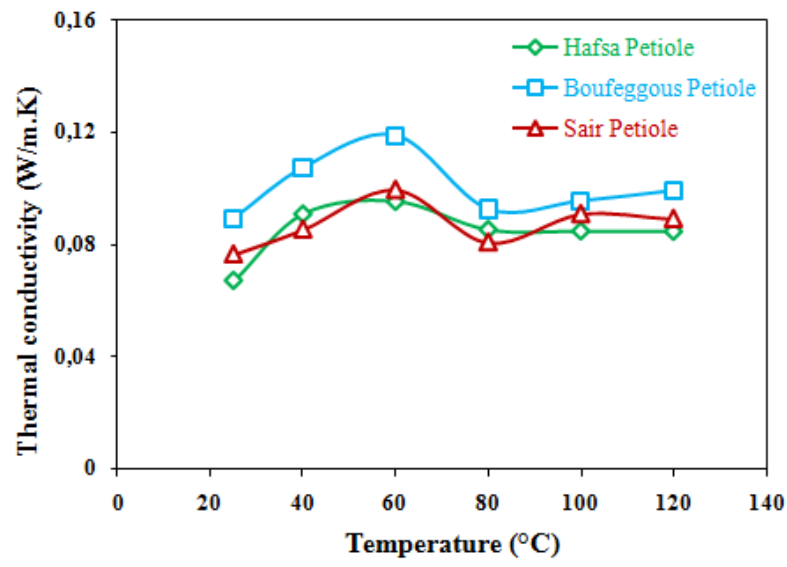

Figure 7. The effect of temperature on thermal conductivity of studied samples in transversal direction of fibers

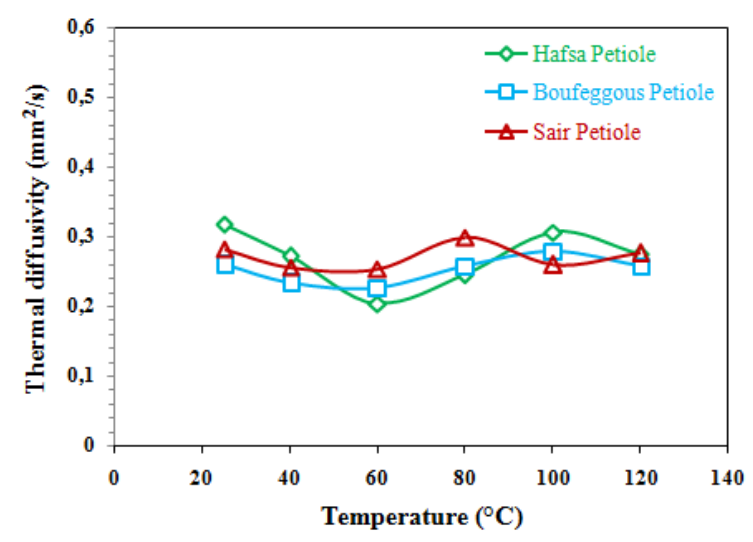

Figure 8. The effect of temperature on thermal diffusivity of studied samples in transversal direction of fibers

\subsection{Study of microstructure}

Natural fibers are classified into three categories: animal, vegetable and mineral fibers. The vegetable fibers generally have a similar morphology. They are composed of many fiber-cells which are formed by primary, secondary and tertiary cell walls and lumens [31]. Figure 9 presents the scanning electron micrographs of PTH (a), PLH (b) and PTB (c); Figure 9(a) and 9(c) show the transverse fiber direction of studied samples. It can be seen that the samples contain cylindrical fibers with irregular and rough surface. The presence of empty slots on the surface should be also remarked. Likewise, the morphology of petiole fibers of date palms is similar to those of coir fiber [32, 33]. Figure 9 (b) presents the longitudinal fiber direction of Hafsa petiole. By observing this microstructure of the sample interface, it can be seen that there is a large number of hollow single fibers collected and bonded by a layer; this confirms the porous 
structure of petiole. These same observations are also reported in the literature on the fibers extracted from the mesh surrounding the date palm tree stems [34-36]. The major constituents of date palm fibers are the same of that of other lingocellulosic fibers including holocellulose (60-75\%), lignin $(20 \%)$ and ash $(1.18 \%)$ [37].

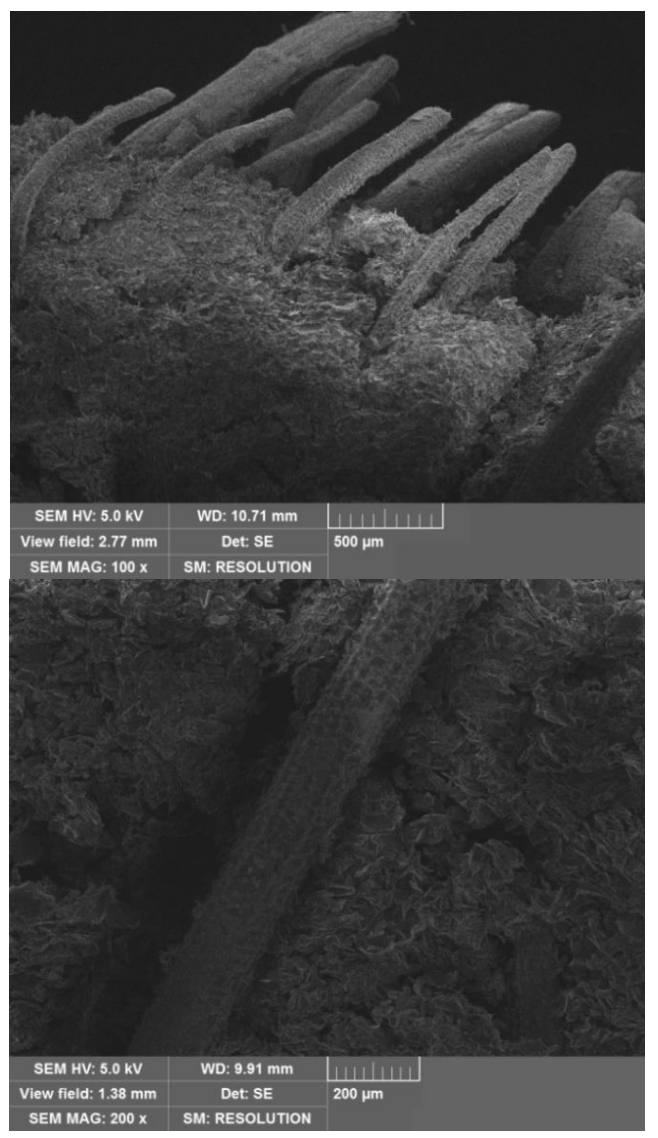

(a) PTH

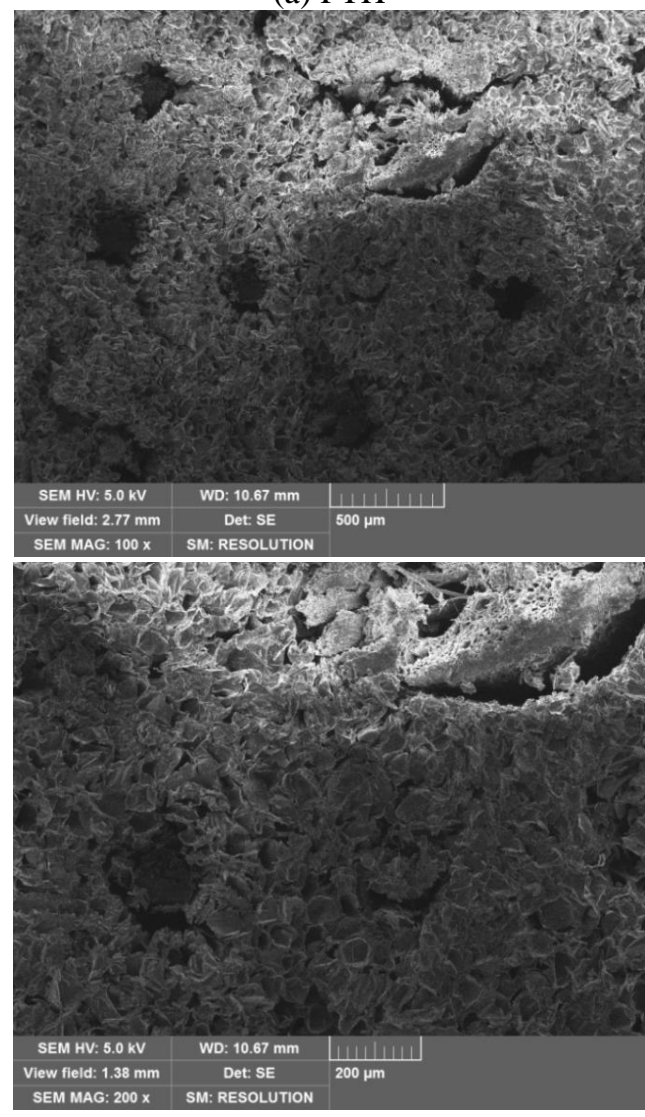

(b) PLH

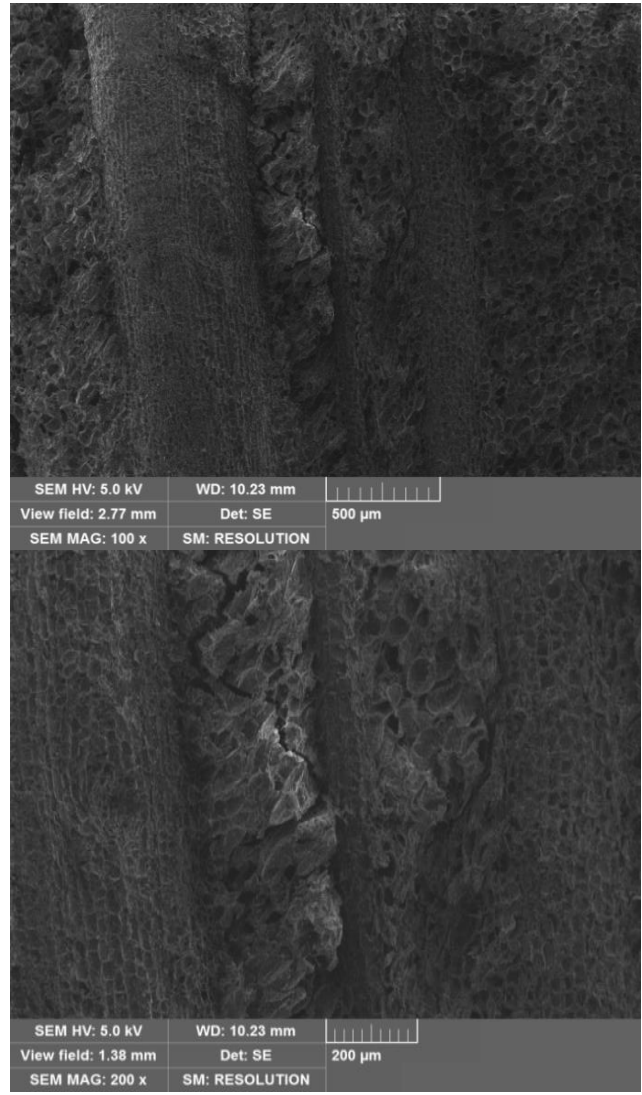

(c) PTB

Figure 9. SEM images for petiole samples

\subsection{Porosity measurement}

Table 2. Different varieties weights before and after drying and immersion in water

\begin{tabular}{ccccc}
\hline & $\begin{array}{c}\text { Bulk } \\
\text { volume } \\
\left(\mathbf{c m}^{\mathbf{3}}\right)\end{array}$ & $\begin{array}{c}\text { Weight } \\
\text { before } \\
\text { drying }(\mathbf{g})\end{array}$ & $\begin{array}{c}\text { Weight } \\
\text { after } \\
\text { drying }(\mathbf{g}) \\
\mathbf{( 9 0} \mathbf{C})\end{array}$ & $\begin{array}{c}\text { Weight } \\
\text { after } \\
\text { immersion } \\
\text { in water }(\mathbf{g})\end{array}$ \\
\hline Hafsa & 1 & 0.2199 & 0.1984 & 0.7351 \\
Sair & 1.6 & 0.4205 & 0.3679 & 1.3209 \\
Boufeggous & 1.2 & 0.4939 & 0.4431 & 1.4331 \\
\hline
\end{tabular}

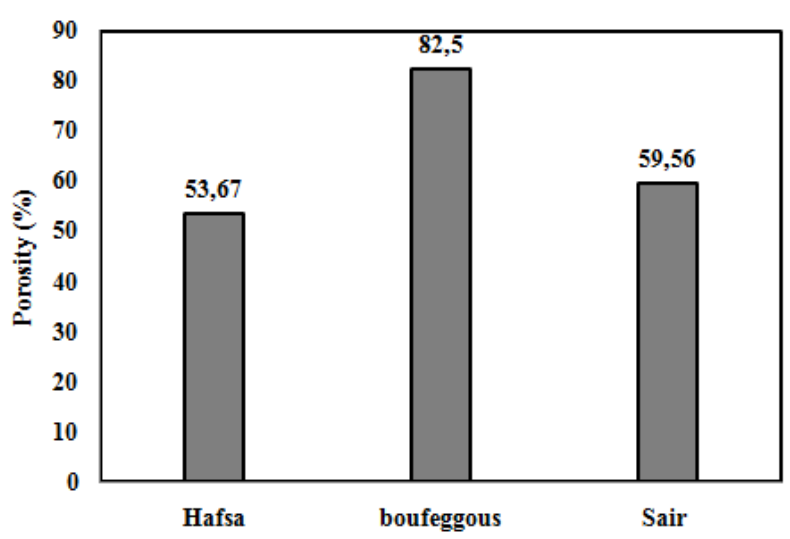

Figure 10. Porosity measurements for the studied samples

Table 2 shows the characteristics of the sample that we used for measuring the fraction of porosity. It is noted that the weight of the samples after immersion in water is about three times greater than the weight of the dried samples, this 
proves that the material has a large absorption capacity and also the presence of voids.

Based on measurements of different petiole samples that are extracted from the three varieties of date palm tree, we can observe that these samples have different fractions of porosity. The total porosity of samples varies between $53.67 \%$ and $82.5 \%$. Porosity plays an important role in determining the thermal properties of the porous materials. It is clear that the thermal conductivity decreased with increasing porosity.

\section{CONCLUSION}

The demand for new ecologically and friendly materials based on renewable natural sources has become a growing topic. This paper reports the results of an experimental investigation on the thermo-physical and morphological properties of a natural material extracted from date palm wood (petiole). The main goal is to evaluate the possibility of using this material in thermal insulation applications (solar cooker in our case). Experimental work was conducted to study some physical properties of three varieties of date palm trees. The effect of fibers orientation and temperature was also studied. The findings from this study reveal low thermal conductivity compared to other conventional materials used in this field .The results of this experimental work have shown that the renewable parts of the palm date (petiole) are good thermal insulators. Therefore we highly recommend to use this alternative material for ecological applications, green building and sustainable thermal devices.

\section{ACKNOWLEDGMENT}

This study was supported by The Moroccan Ministry of Higher Education and Research in the framework of (PPR/2015/31) project.

\section{REFERENCES}

[1] Saheb, N., Jog, J. (2015). Natural fiber polymer composites: A review. Advanced Advances in Polymer Technology, 18(4):

351-363 https://doi.org/10.1002/(SICI)10982329(199924)18:4<351::AID-ADV6>3.0.CO;2-X

[2] Mohanty, A.K., Misra, M., Hinrichsen, G. (2000). Biofibres biodegradable polymers and biocomposites: An overview. Macromolecular Materials and Engineering, 276-277: 1-24. https://doi.org/10.1002/(SICI)14392054(20000301)276:1<1::AID-MAME1>3.0.CO;2-W

[3] Agoudjil, B., Benchabane, A., Boudenne, A., Ibos, L., Fois, M. (2011). Renewable materials to reduce building heat loss: Characterization of date palm wood. Energy Builduig, 43(2-3): 491-497. https://doi.org/10.1016/j.enbuild.2010.10.014

[4] FAOSTAT. (2015). Food and agriculture organization of the united nations statistics division, données statistiques de production végétale. FAOSTAT Database website: faostat3.fao.org

[5] Baaziz, M., Bendiab, K. (2008). Les palmeraies du Maghreb. Quelle amélioration génétique dans un contexte d' érosion de la diversité génétique de Phoenix dactylifera L.?. Colloque 'Biotechnologies végétales et gestion durable des résistances face à des stress biotiques et abiotiques. Rennes 30 Juin- 03 Juillet.

[6] Barreveld, W.H. (1993). Date Palm Products. Food and Agriculture Organization of the United Nations Rome. FAO Agric. Serv.

[7] Tiskatine, R., Bougdour, N., Oaddi, R., Gourdo, L., Rahib, Y., Bouzit, S., Bazgaou, A., Bouirden, L., Ihlal, A., Aharoune, A. (2018). Thermo-physical analysis of low-cost ecological composites for building construction. Journal of Building Engineering, 20: 762775. https://doi.org/10.1016/j.jobe.2018.09.015

[8] Ali, M.E., Alabdulkarem, A. (2017). On thermal characteristics and microstructure of a new insulation material extracted from date palm trees surface fibers. Construction and Building Materials, 138: 276-284. https://doi.org/10.1016/j.conbuildmat.2017.02.012

[9] Boulaoued, I., Amara, I., Mhimid, A. (2016) Experimental determination of thermal conductivity and diffusivity of new building insulating materials. International Journal of Heat and Technology, 34(2): 325-331, 2016. https://doi.org/10.18280/ijht.340224

[10] Asdrubali, F., D’Alessandro, F., Schiavoni, S. (2015). A review of unconventional sustainable building insulation materials. Sustainble Materials and Technology, 4: 1-17. https://doi.org/10.1016/j.susmat.2015.05.002

[11] Benmansour, N., Agoujil, B., Gherabli, A., Kareche, A., Boudenne, A. (2014). Thermal and mechanical performance of natural mortar reinforced with date palm fibers for use as insulating materials in building. Journal of Energy and Building, 81: 98-104. http://dx.doi.org/10.1016/j.enbuild.2014.05.032

[12] Chikhi, M., Agoudjil, B., Boudenne, A., Gherabli, A. (2013). Experimental invistigation of new biocomposite with low cost for thermal insulation. Journal of Energy and Building, 66: 267-273. http://dx.doi.org/10.1016/j.enbuild.2013.07.019

[13] Chikhi, M. (2016). Young's modulus and thermophysical performance of bio-sourced materials based on date palm fibers. Journal of Energy and Building, 129: 589-597. http://dx.doi.org/10.1016/j.enbuild.2016.08.034

[14] Jelle, B.P. (2011). Traditional, state-of-the-art and future thermal building insulation materials and solutions - Properties, requirements and possibilities. Energy and Builduig, 43(10): 2549-2563. https://doi.org/10.1016/j.enbuild.2011.05.015

[15] Berardi, U., Naldi, M. (2017). The impact of the temperature dependent thermal conductivity of insulating materials on the effective building envelope performance. Energy and Building, 144: 262-275. https://doi.org/10.1016/j.enbuild.2017.03.052

[16] Tilioua, A., Libessart, L., Lassue, S. (2018). Characterization of the thermal properties of fibrous insulation materials made from recycled textile fi bers for building applications: Theoretical and experimental analyses. Applied Thermal Engineering, 142: 56-67. https://doi.org/10.1016/j.applthermaleng.2018.06.071

[17] Gustafsson, S.E. (1991). Transient plane source techniques for thermal conductivity and thermal diffusivity measurements of solid materials. Review of Scientific Instruments, 62(3): 797-804. 
https://doi.org/10.1063/1.1142087

[18] Suleiman, B.M., Larfeldt, J., Leckner, B., Gustavssor, M. (1999). Thermal conductivity and diffusivity of wood. Wood Science and Technology, 33(6): 465-473. https://doi.org/10.1007/s002260050130

[19] BSI BS EN ISO 12571 (2013) Hygrothermal Performance of Building Materials and Products Determination of Hygroscopic Sorption Properties the British Standard.

[20] Suleiman, B.M., Larfeldt, J., Leckner, B., Gustavssor, M. (1999). Thermal conductivity and diffusivity of wood. Wood Science and Technology, 33(6): 465-473. https://doi.org/10.1007/s002260050130

[21] Nguyen, S.T., Tran-Le, A.D., Vu, M.N., To, Q.D., Douzane, O., Langlet, T. (2016). Modeling thermal conductivity of hemp insulation material: A multi-scale homogenization approach. Building and Environment. 107: https://doi.org/10.1016/j.buildenv.2016.07.026

$127-134$

[22] Paiva, A., Pereira, S., Sá, A., Cruz, D., Varum, H., Pinto, J. (2012). A contribution to the thermal insulation performance characterization of corn cob particleboards. Energy and Building, 45: 274-279. https://doi.org/10.1016/j.enbuild.2011.11.019

[23] Pinto, J., Cruz, D., Paiva, A., Pereira, S., Tavares, P., Fernandes, L., Varum, H. (2012). Characterization of corn cob as a possible raw building material. Construction and Building Materials, 34: 28-33. https://doi.org/10.1016/j.conbuildmat.2012.02.014

[24] Goodhew, S., Griffiths, R. (2005). Sustainable earth walls to meet the building regulations. Energy and Building, 37(5): 451-459. https://doi.org/10.1016/j.enbuild.2004.08.005

[25] Pruteanu, M. (2010). Investigations regarding the thermal conductivity of straw. Bulletin of the Polytechnic Institute of Jassy - Construction. Architecture Section. LVI (LX): 9-16.

[26] Panyakaew, S., Fotios, S. (2011). New thermal insulation boards made from coconut husk and bagasse. Energy and Building, 43(7): 1732-1739. https://doi.org/10.1016/j.enbuild.2011.03.015

[27] Volf, M., Divišs, J., Havlík, F. (2015). Thermal, moisture and biological behaviour of natural insulating materials. Energy Procedia, 78: 1599-1604. https://doi.org/10.1016/j.egypro.2015.11.219

[28] Maya JacobJohn, S., Thomas, S. (2008). Biofibres and biocomposites. Carbohydrate Polymers, 71(3): 343-364. https://doi.org/10.1016/j.carbpol.2007.05.040

[29] Zhang, H.M. (2011). Building Materials in Civil Engineering. Woodhead Publishing, 304-423.

[30] Peavy, B.A. (1996). A Heat transfer note on temperature dependent thermal conductivity. Journal of Building Physics, 20(1): 76-90. https://doi.org/10.1177/109719639602000107

[31] Byron Bird, R., Stewart, W.E., Lighfoot, E.N. (2006). Transport Phenomena. Second Edition.

[32] Alves Fidelis, M.E., Pereira, T.V.C., Gomes, O.D.F.M., De Andrade Silva, F,. Toledo Filho, D. (2013). The effect of fiber morphology on the tensile strength of natural fibers. Journal of Materials Research and Technology,

2(2):

149-157. https://doi.org/10.1016/j.jmrt.2013.02.003

[33] Kriker, A., Debicki, G., Bali, A., Khenfer, M.M., Chabannet, M. (2005). Mechanical properties of date palm fibres and concrete reinforced with date palm fibres in hot-dry climate. Cement and Concrete Composites, 27(5): 554-564. https://doi.org/10.1016/j.cemconcomp.2004.09.015

[34] Barkoula, N.M., Alcock, B., Cabrera, N.O., Peijs, T. (2008). Recent developments in chemical modification and characterization of natural fiber-reinforced composites. Polymer Composites, 16(2): 101-113. https://doi.org/10.1002/pc.20461

[35] Al-Khanbashi, A., Al-Kaabi, K., Hammami, A. (2005). Date palm fibers as polymeric matrix reinforcement: Fiber characterization. Polymer Composites, 26(4): 486-497. https://doi.org/10.1002/pc.20118

[36] Kriker, A., Bali, A., Debicki, G., Bouziane, M., Chabannet, M. (2008). Durability of date palm fibres and their use as reinforcement in hot dry climates. Cement and Concrete Composites, 30: 639-648. https://doi.org/10.1016/j.cemconcomp.2007.11.006

[37] Al-Oqla, F.M., Alothman, O.Y., Jawaid, Y., M, Sapuan S.M. (2014). Processing and properties of date palm fibers and its composites. Biomass and Bioenergy, 1-25. https://doi.org/10.1007/978-3-319-07641-6_1

\section{NOMENCLATURE}

$\mathrm{k}$

$\mathrm{T}$

$\mathrm{X}$

A

$\mathrm{t}$

q

a

c

$\mathrm{V}_{\mathrm{p}}$

$\mathrm{V}_{\mathrm{b}}$

Thermal conductivity, W/ m.K

Temperature, $\mathrm{K}$

Thikness, $\mathrm{m}$

Surface area, $\mathrm{m}^{2}$

Time, $\mathrm{s}$

Heat flux, W/ m²

Thermal diffusivity, $\mathrm{m}^{2} / \mathrm{s}$

Specific heat capacity, J/ kg.K

Viod space, $\mathrm{m}^{3}$

Bulk volume, $\mathrm{m}^{3}$

\section{Greek symbols}

К

$\rho$

Thermal conductivity for anisotropic materials, W/ m.K

Mass density, $\mathrm{kg} / \mathrm{m}^{3}$

$\phi \quad$ Solid volume fraction (\%)

\section{Subscripts}

PTH Hafsa petiole in transversal direction of fibers

PTB Boufeggous petiole in transvesal direction of fibers

PTS Sair petiole in transvesal direction of fibers

PLH Hafsa petiole in longitudinal direction of fibers

PLB Boufeggous petiole in longitudinal direction of fibers 